\title{
Analisis Kebutuhan Bahan Ajar Matematika Berbasis Teknologi Informasi (TI) di SMA IT Al Bayyinah Pekanbaru
}

\author{
Heni Rahmadani ${ }^{1}$, Yenita Roza ${ }^{2}$, Atma Murni ${ }^{3}$ \\ ${ }^{1,2,3}$ Magister of Mathematics Education Departement, Universitas Riau \\ e-mail: heni.rahmadani7368@grad.unri.ac.id
}

\begin{abstract}
This article aims to present the results of the analysis of teaching materials needs of IT-based trigonometric functions. The data in this article was collected through questionnaires through the help of google form which was filled by three mathematics teachers and 20 high school students of SMA IT Al-bayyinah at the end of the academic year 2017/2018, then analyzed by using descriptive analysis. The study objects in this article include: 1) KI and KD conformity, 2) teaching materials used by teachers, and 3) teacher and student needs related to IT-based learning materials. The results show that: 1) All material on teaching materials is in accordance with KI and $\mathrm{KD} 3.11 ; 2)$ Teachers and students use materials other than books from schools to assist in understanding a material; and 3) Teachers and students need IT-based teaching materials that can be used to study the concept of trigonometric functions, because it is in line with the development of information and technology. Thus, it is understood that IT-based teaching materials are required.
\end{abstract}

Keywords: Analysis, Materials, Mathematics, Information and Technology (IT).

\begin{abstract}
ABSTRAK. Artikel ini bertujuan untuk mengemukakan hasil analisis kebutuhan bahan ajar fungsi trigonometri berbasis TI. Data dalam artikel ini dikumpulkan melalui penyebaran angket melalui bantuan google form yang diisi oleh tiga orang guru matematika dan 20 orang siswa kelas X SMA IT Al-bayyinah semester genap tahun ajaran 2017/2018, lalu dianalisis dengan menggunakan analisis deskriptif. Objek kajian dalam artikel ini mencakup: 1) kesesuain KI dan KD, 2) bahan ajar yang digunakan guru, dan 3) kebutuhan guru dan siswa terkait bahan ajar berbasis TI. Hasil menunjukkan bahwa: 1) Semua materi pada bahan ajar sudah sesuai dengan KI dan KD 3.11; 2) Guru dan siswa menggunakan bahan lain selain buku dari sekolah untuk membantu dalam memahami suatu materi; dan 3) Guru dan siswa membutuhkan bahan ajar berbasis IT yang dapat digunakan untuk mempelajari konsep fungsi trigonometri, karena sejalan dengan perkembangan informasi dan teknologi. Dengan demikian, dapat dipahami bahwa bahan ajar berbasis IT diperlukan.
\end{abstract}

Kata kunci: Analisis, Bahan Ajar, Matematika, Teknologi Informasi (TI).

\section{PENDAHULUAN}

Pada tahun ajaran 2013/2014 kurikulum di Indonesia mengalami transisi dari Kurikulum 2006 menjadi Kurikulum 2013. Pelajaran yang diterapkan di satuan pendidikan terutama di jenjang pendidikan dasar terlalu padat dan tumpang tindih, sehingga kurikulum 2006 disempurnakan dalam kurikulum 2013 (Machali, 2014). Kurikulum 2013 bertujuan untuk mendorong siswa agar mampu lebih baik dalam melakukan observasi, bertanya, bernalar, dan mengomunikasikan (mempresentasikan) yang mereka peroleh atau mereka ketahui setelah menerima materi pembelajaran di sekolah (Anwar, 2013). Siswa akan lebih kreatif, inovatif, dan lebih produktif, sehingga nantinya mereka bisa sukses dalam menghadapi berbagai persoalan dan tantangan yang mereka temukan dalam kegiatan pembelajaran. Kegiatan pembelajaran dalam skema Kurikulum 2013 diselenggarakan untuk membentuk watak, membangun pengetahuan, sikap dan kebiasaankebiasaan untuk meningkatkan mutu kehidupan siswa (Ibrahim, 2015). Kegiatan pembelajaran 
diharapkan mampu memberdayakan semua potensi siswa untuk menguasai kompetensi yang diharapkan. Siswa mampu mengembangkan sikap dan pengalaman sesuai dengan potensinya sehingga peran guru tidak lagi sebagai pemberi ilmu, melainkan sebagai fasilitator atau membantu siswa agar siswa mampu menguasai berbagai kompetensi yang diharapkan kurikulum.

Implementasi Kurikulum 2013 menuntut pemahaman guru secara komprehensif tentang konsep, penyusunan, serta ketersediaan sarana dan prasarana. Guru memiliki peranan penting dalam mengimplementasikan kurikulum, salah satu keberhasilan kurikulum bergantung pada aktivitas dan kreativitas guru dalam mengembangkan dan merealisasikannya. Guru juga harus mampu melaksanakan proses pembelajaran sesuai dengan Peraturan Menteri Pendidikan dan Kebudayaan (Permendikbud) Nomor 22 Tahun 2016 tentang standar proses pendidikan dasar dan menengah.

Pelaksanaan proses pembelajaran menurut hasil observasi termasuk ke dalam kriteria kurang terlaksana. Proses pembelajaran yang dilakukan guru tidak sesuai dengan RPP yang disusun sehingga guru belum sepenuhnya mengimplementasikan proses pembelajaran dalam Kurikulum 2013. Pelaksanaan proses pembelajaran berdampak pada kualitas peserta didik. Pelaksanaan pembelajaran seharusnya berjalan dengan efektif, efisien dan bermakna sehingga ilmu yang dipelajari dapat terserap dengan baik (Mira Susanti, Nevrita, 2017). Persiapan guru untuk implementasi Kurikulum 2013 tergesa-gesa dan kurang maksimal, akibatnya banyak guru yang tidak tahu bagaimana menyusun Kurikulum 2013, kurangnya penguasaan teknologi informasi, kurangnya antusias guru, dan kesulitan mencari buku/literatur yang mendukung. Kendala pada penerapan Kurikulum 2013 dapat diminimalisir salah satunya dengan mengembangkan bahan ajar yang sesuai kebutuhan siswa. Penggunaan buku cetak dalam pembelajaran matematika terkadang kurang maksimal, peserta didik masih mencatat materi yang guru sampaikan padahal materi tersebut sudah terdapat dalam buku. Jika melihat lebih jauh lagi bahan ajar buku cetak membutuhkan banyak pengeluaran untuk mencetaknya ditambah lagi hutan yang saat ini semakin hilang pohonnya untuk dijadikan kertas (Saluky, 2016).

Berdasarkan hasil wawancara dengan beberapa siswa kelas X SMA IT Albayyinah Pekanbaru pada tanggal 11 Desember 2017, dapat disimpulkan bahwa: (1) guru jarang memberikan siswa LKPD, sehingga siswa jarang menemukan sendiri informasi yang dia peroleh; (2) siswa mengalami kesulitan memanfaatkan media/buku yang ada karena materi-materi pembelajaran tersebar pada beberapa buku yang berbeda; (3) buku ajar yang beredar dari pemerintah memiliki bahasa yang sulit untuk siswa pahami; (4) siswa kesulitan dalam memahami materi matematika yang bersifat abstrak, khususnya materi fungsi trigonometri yang menuntut keterampilan siswa dalam memahami konsep trigonometri dan menggambar fungsi trigonometri. Penggunaan bahan ajar dapat mempengaruhi hasil belajar matematika siswa. Berdasarkan wawancara, siswa kesulitan dalam memahami materi trigonometri sehingga berdampak terhadap persentase ketuntasan hasil belajar matematika peserta didik masih rendah pada materi trigonometri, tidak mencapai standar KKM yang telah ditetapkan oleh guru. Hal ini sejalan dengan hasil penelitian yang menyatakan bahwa $60 \%$ of student reveal that mathematics is much complex to understated in comparison to other subjects. Again, $48 \%$ of students convey that in mathematics lots of formula are to be memorized specially in algebra, trigonometry and calculus (60\% siswa menyatakan bahwa matematika lebih kompleks untuk dipahami dibandingkan dengan mata pelajaran lainnya. Juga, 48\% siswa menyampaikan bahwa matematika memiliki banyak rumus yang harus diingat khususnya dalam materi aljabar, trigonometri dan kalkulus) (Kaushik \& Singh, 2013).

Hal tersebut sejalan dengan pengalaman penulis sebagai guru, bahwa trigonometri sebagai salah satu materi yang dikeluhkan siswa karena banyaknya rumus yang tidak saja harus dihafal tetapi juga memerlukan pemahaman tinggi dalam penerapannya (Kaushik \& Singh, 2013). Materi matematika yang bersifat abstrak, khususnya trigonometri dapat diminimalisir dengan menyajikan materi menggunakan animasi-animasi yang memanfaatkan penggunaan Infomasi dan Teknologi 
(IT). Dengan perkembangan teknologi, saat ini mulai dikembangkan berbagai media pembelajaran diantaranya adalah bahan ajar. Jenis-jenis bahan ajar, diantaranya: (1) bahan ajar visual yang terdiri atas bahan cetak seperti handout, buku, modul, lembar kerja siswa, brosur, gambar, dan lain-lain; (2) bahan ajar audio misalnya kaset, radio, piringan hitam, dan compact disk audio; (3) bahan ajar audio visual seperti, video compact disk, film; (4) bahan ajar multi media interaktif seperti bahan ajar yang berbasis computer dan web (Jenny Indrastoeti SP, 2017). Salah satu jenis bahan ajar yang dikemukakan Jenny Indrastoeti SP, Siti Istiyat adalah bahan ajar berbasis komputer. Melalui pemanfaatan media berbasis IT, siswa disiapkan untuk memaknai segala informasi dan menciptakannya menjadi pengetahuan untuk kemudian dapat menggunakan dan mengevaluasi yang diciptakan oleh orang lain (Halidi, Hasan Mahmud, 2015).

Masalah-masalah yang dikemukakan berdasarkan wawancara dan observasi dengan beberapa guru dan siswa menjadi landasan penulis untuk menganalisis bahan ajar berbasis IT pada materi Fungsi Trigonometri yang sesuai dengan tuntutan dan harapan dalam Kurikulum 2013 untuk siswa kelas X. Bahan ajar berbasis IT merupakan salah satu cara yang dapat digunakan untuk membuat siswa secara aktif karena bahan ajar memuat serangkaian pengalaman belajar yang disusun secara sistematis dan dapat membantu siswa mencapai tujuan belajar dengan dilengkapi beberapa animasi yang akan membuat pemahaman siswa terhadap suatu konsep meningkat. Hasil belajar siswa dapat meningkat karena bahan ajar dirancang dengan desain yang menarik, memuat masalah yang berbeda, dan tersedia langkah-langkah untuk menyelesaikan masalah. Bahan ajar dirancang sesuai Kurikulum 2013 yang mencakup pendekatan saintifik dengan proses belajar mengamati, menanya, mengumpulkan informasi, mengasosiasi, dan mengomunikasikan sehingga siswa menemukan sendiri konsep berdasarkan hasil percobaan yang dilakukan. Berdasarkan latar belakang tersebut, maka artikel ini memiliki tujuan untuk untuk menganalisis kebutuhan bahan ajar berbasis IT untuk siswa kelas di SMA IT Al Bayyinah Pekanbaru.

\section{TINJAUAN LITERATUR}

Bahan ajar merupakan kelengkapan yang diperlukan dan dipergunakan oleh guru ketika mengajar (Maharani, 2017). Sesuai dengan isi pada juknis pengembangan bahan ajar SMA yang disampaikan direktorat Pembinaan SMA bahwa bahan ajar adalah segala bentuk bahan berupa perangkat materi yang disusun secara sistematis yang digunakan untuk membantu guru dalam melaksanakan kegiatan pembelajaran dan memungkinkan peserta didik untuk belajar (Direktorat Pembinaan SMA, 2010). Dari beberapa pandangan mengenai pengertian bahan ajar tersebut, dapat kita pahami bahwa bahan ajar merupakan segala bahan (baik informasi, alat, maupun teks) yang disusun secara sistematis yang menampilkan sosok utuh dari kompetensi yang akan dikuasai peserta didik dan digunakan dalam proses pembelajaran dengan tujuan perencanaan dan penelaahan implementasi pembelajaran.

Jenis bahan ajar berupa: 1) bahan ajar cetak (printed), antara lain hand out, buku, modul, poster, brosur, lembar kerja siswa (LKS), wallchart, foto atau gambar, dan leaflet, 2) bahan ajar dengar (audio) seperti kaset, radio, piringan hitam, dan compact disk audio; 3) bahan ajar pandang dengar ( audio visual) seperti compact disc video, film; dan 4) bahan ajar multimedia interaktif (interactive teaching material) seperti CAI (Computer Assisted Instruction), compact disk (CD) multimedia pembelajaran interaktif, dan bahan ajar berbasis web (web based learning materials) (Maharani, 2017).

Tujuan penyusunan bahan ajar, yakni: 1) menyediakan bahan ajar yang sesuai dengan tuntutan kurikulum dengan mempertimbangkan kebutuhan siswa, sekolah, dan daerah; 2) membantu siswa dalam memperoleh alternatif bahan ajar; dan 3) memudahkan guru dalam melaksanakan pembelajaran" (Departemen Pendidikan Nasional, 2008). Secara garis besar, fungsi bahan ajar bagi guru adalah untuk mengarahkan semua aktivitasnya dalam proses pembelajaran sekaligus merupakan subtansi kompetensi yang seharusnya diajarkan kepada siswa. Fungsi bahan 
ajar bagi siswa untuk menjadi pedoman dalam proses pembelajaran dan merupakan subtansi kompetensi yang seharusnya dipelajari. Bahan ajar juga berfungsi sebagai alat evaluasi pencapaiana hasil pembelajaran. Penggunaan bahan ajar berfungsi sebagai berikut: (1) pedoman bagi guru yang akan mengarahkan semua aktivitasnya dalam proses pembelajaran, sekaligus meruapakan substansi kompetensi yang seharusnya diajarkan kepada siswa, (2) pedoman bagi siswa yang akan mengarahkan semua aktivitasnya dalam proses pembelajaran, sekaligus merupakan substansi kompetensi yang seharusnya dipelajari atau dikuasai, (3) alat evaluasi pencapaian atau penguasaan hasil pembelajaran (Mochamad Guntur, Arif Muchyidin, 2017). Dia juga mengatakan bahwa tujuan dari pembuatan bahan ajar sebagai berikut: (1) Membantu peserta didik dalam mempelajari sesuatu, (2) Menyediakan berbagai jenis pilihan bahan ajar, sehingga mencegah timbulnya rasa bosan pada peserta didik, (3) Memudahkan peserta didik dalam melaksanakan pembelajaran, dan (4) Kegiatan pembelajaran lebih menarik (Mochamad Guntur, Arif Muchyidin, 2017).

Bahan ajar yang baik sekurang-kurangnya mencakup petunjuk belajar, kompetensi yang akan dicapai, isi pelajaran, informasi pendukung, latihan-latihan, petunjuk kerja, evaluasi dan respon terhadap hasil evaluasi (Ika Lestari, 2011). Perancangan bahan ajar menjadi hal yang sangat penting dalam proses pembelajaran. Bahan ajar yang dikembangkan harus mampu meningkatkan motivasi dan efektivitas penggunanya. Widodo "mengungkapkan ada lima karakteristik bahan ajar yaitu 1) self instructional, 2) self contained, 3) stand alone, 4) adaptif, dan 5) user friendly (Ika Lestari, 2011).

Perkembangan ilmu pengetahuan dan teknologi memungkinkan semua pihak dapat memperoleh informasi dengan melimpah, cepat, dan mudah dari berbagai sumber dan tempt di dunia (Maharani, 2017). Dengan demikian, siswa perlu dibekali kemampuan memperoleh, memilih, dan mengelola informasi untuk bertahan pada keadaan yang selalu berubah, tidak pasti, dan kompetitif. Salah satu pemanfataan perkembangan dalama dunia pendidikan adalah pengembangan bahan ajar berbasis IT. Bahan ajar berbasis IT merupakan bahan ajar yang menggunakan teknologi sebagai alat bantu dalam mengolah data, termasuk memproses, mendapatkan, menyusun, menyimpan, memanipulasi data dalam berbagai cara untuk menghasilkan informasi yang berkualitas. Dalam kegiatan pembelajaran, penggunaan bahan ajar IT memungkinkan peserta didik dapat mempelajari suatu kompetensi dasar (KD) secara runtut, sistematis, interaktif dan inovatif sehingga diharapkan semua kompetensi tercapai secara utuh dan terpadu.

Peran penting Bahan Ajar berbasis TIK dalam proses pembelajaran didasari oleh karakteristik Bahan Ajar yang lebih kompleks dibanding jenis bahan ajar lain. Beberapa karakteristik Bahan Ajar berbasis TIK antara lain: 1) memanfaatkan keunggulan komputer (digital media ataupun teknologi jaringan/computer network); 2) memanfaatkan teknologi multimedia, sehingga suasana pembelajaran menjadi menarik, tidak membosankan dan pada akhirnya memotivasi peserta didik untuk belajar mandiri; 3) memanfaatkan teknologi elektronik; di mana pendidik dan peserta didik, peserta didik dan sesama peserta didik atau pendidik dan sesama pendidik dapat berkomunikasi dengan relatif mudah tanpa dibatasi oleh hal-hal yang protokoler; 4) menggunakan bahan ajar bersifat mandiri (self learning materials) disimpan di komputer sehingga dapat diakses oleh pendidik dan peserta didik kapan saja dan di mana saja bila yang bersangkutan memerlukannya; dan 5) memanfaatkan Pertukaran Data (Information sharing) yang secara interaktif dapat dilihat setiap saat di computer (Direktorat Pembinaan SMA, 2010). Lebih lanjutnya, bahan ajar berbasis TIK memiliki keunggulan antara lain sebagai berikut: 1) memberikan kemudahan bagi pendidik dalam proses pembelajaran untuk menjelaskan hal-hal yang abstrak; 2) berubahnya peran peserta didik dari yang biasanya pasif menjadi aktif serta mempunyai ketertarikan pada materi yang sedang dibahas; 3) peserta didik dapat belajar atau menelaah bahan aja sewaktu-waktu karena bahan ajar dapat tersimpan di computer; 4) pendidik dan peserta didik dapat menggunakan bahan ajar atau petunjuk belajar yang terstruktur dan terjadwal melalui jaringan intranet atau internet, sehingga keduanya bisa saling menilai sampai berapa jauh bahan ajar dipelajari; 5) tersedianya fasilitas e-moderating di mana pendidik dan peserta didik dapat berkomunikasi secara mudah melalui 
fasilitas internet secara regular atau kapan saja kegiatan berkomunikasi itu dilakukan dengan tanpa dibatasi oleh jarak, tempat dan waktu; dan 6) baik pendidik maupun peserta didik dapat melakukan diskusi dan berinteraksi melalui fasilitas-fasilitas internet yang dapat dilakukan secara kelompok/group (Direktorat Pembinaan SMA, 2010).

\section{METODE}

Artikel ini menggunakan penelitian pengembangan (Research and development) yang merupakan penelitian dengan tujuan untuk membuat produk melalui pengujian efektifitas produk tersebut. Pengembangan bahan ajar berbasis TI ini menggunakan model pengembangan ADDIE (Analisys, Design, Development, Implementation, Evaluation). Namun pada artikel ini, tahapan penilitian hanya dibatasi pada tahap analisis kebutuhan saja. Sejalan dengan hal tersebut, artikel ini digunakan untuk menganalisis kebutuhan bahan ajar matematika berbasis IT untuk siswa kelas X SMA IT Al Bayyinah Pekanbaru.

Subjek dalam artikel ini adalah siswa dan guru SMA IT Al Bayyinah Pekanbaru. Analisis kebutuhan ini dilaksanakan pada 28 Mei 2018 dari 3 (tiga) orang guru matematika dan 20 (dua puluh) siswa kelas X SMA IT Albayyinah Pekanbaru. Objek kajian dalam artikel ini mencakup: 1) kesesuain KI dan KD, 2) bahan ajar yang digunakan guru, 3) kebutuhan guru dan siswa terkait bahan ajar berbasis TI, dan 4) kesulitan siswa dalam mempelajari materi fungsi trigonometri. Pengumpulan data dilakukan dengan menggunakan angket melalui bantuan google form yang diaanalisis data dilakukan dengan deskriptif.

\section{HASIL}

Penulis menanyakan beberapa pertanyaan untuk guru dan siswa melalui angket, pertanyaan untuk guru terdiri dari 6 pertanyaan dan pertanyaan oleh siswa terdiri 9 pertanyaan. Hasil dari pengisian angket guru, yaitu: 1) 67\% guru memiliki buku teks atau buku pegangan lain untuk belajar materi fungsi trigonometri; 2) 100\% bahan ajar yang digunakan sudah sesuai dengan KI dan KD; 3) $100 \%$ guru mencari bahan lain selain buku dari sekolah untuk membantu dalam memahami suatu materi, misalnya melalui bahan ajar atau internet; 4) 33\% guru menggunakan bahan ajar khusus untuk membelajarkan konsep fungsi trigonometri; 5) 100\% guru membutuhkan bahan ajar berbasis IT yang dapat digunakan untuk mempelajari konsep fungsi trigonometri agar lebih mudah dan menarik; dan 6) 100\% guru setuju apabila dikembangkan bahan ajar berbasis IT untuk membelajarkan konsep fungsi trigonometri sehingga konsep tersebut mudah dipahami.

Hasil wawancara siswa yaitu; 1) $90 \%$ siswa memiliki buku teks atau buku pegangan lain untuk belajar materi fungsi trigonometri; 2) $80 \%$ siswa mencari bahan lain selain buku dari sekolah untuk membantu dalam memahami suatu materi; 3) 80\% siswa mengalami kesulitan mempelajari sub materi fungsi trigonometri dari buku teks tersebut; 4) $90 \%$ siswa diberi bahan ajar agar lebih mudah memahami konsep fungsi trigonometri; 5) 50\% siswa antusias mengikuti pembelajaran pada materi fungsi trigonometri; 6) $80 \%$ siswa menganggap materi fungsi trigonometri sulit dipahami; 7) 45\% siswa mengalami kesulitan memahami materi fungsi trigonometri melalui bahan ajar dan metode yang diterapkan guru; 8) 80\% siswa membutuhkan bahan ajar berbasis IT yang dapat digunakan untuk mempelajari konsep fungsi trigonometri agar lebih mudah dan menarik; dan 9) $90 \%$ siswa setuju apabila dikembangkan bahan ajar berbasis IT untuk membelajarkan konsep fungsi trigonometri sehingga konsep tersebut mudah dipahami.

Berdasarkan hasil rangkuman penyebaran angket guru maupun siswa, siswa dan guru setuju untuk menggunakan bahan ajar berbasis IT dimana bahan ajar tersebut dapat dimanfaatkan 
secara individu dan kelompok dengan melibatkan siswa dan guru sebagai fasilitator. Hal ini dikarenakan pada bahan ajar berbasis IT konsep pembelajaran yang menekankan kemandirian seluruh siswa dalam memahami isi materi yang diberikan guru agar siswa dapat dengan mudah memahami isi materi yang diberikan guru, kemudian akan terwujudnya berbagai macam pemikiran dan berbagai pemahaman terhadap siswa. Oleh karena itu, keberadaan bahan ajar pada proses pembelajaran matematika sangat penting. Siswa masih mengatakan bahwa bahan ajar yang digunakan memberikan kesulitan kepada siswa dalam mempelajari sub materi fungsi trigonometri dari. Hal ini membuktikan bahwa bahan ajar yang ada belum mampu menampilkan komponen dari setiap materi dengan mengimplikasikanya dengan kehidupan sehari-hari. Dengan demikian, masih perlu dikembangkan bahan ajar matematika berbasis IT.

\section{PEMBAHASAN}

Sejalan dengan tujuan penelitian yaitu untuk menganalisis kebutuhan bahan ajar berbasis IT. Hasil analisis angket analisis kebutuhan siswa SMA IT Al Bayyinah Pekanbaru dapat di identifikasi bahwa guru dan siswa sangat setuju dan mendukung adanya pembuatan dan pengembangan bahan ajar berbasis IT pada mata pelajaran Matematika. Berdasarkan temuan-temuan yang diperoleh dari hasil analisis, penulis menemukan perlunya dilakukan perbaikan dan peningkatan kualitas pembelajaran matematika di SMA IT Al Bayyinah Pekanbaru. Salah satu hal yang perlu dilakukan adalah peningkatan kualitas kemampuan guru dalam merancang dan melaksanakan kegiatan pembelajaran matematika serta pengadaan dan penambahan bahan ajar yang dapat meningkatkan minat dan motivasi siswa. Hal ini dapat dilakukan dengan memberi pembekalan pengetahuan dan kemampuan kepada guru dalam merancang dan melaksanakan kegiatan dalam pembelajaran matematika, sekaligus mengembangkan bahan ajar seperti bahan ajar berbasis IT.

Berdasarkan permasalahan pada tahap analisis yang telah dijelaskan dalam hasil penelitian diketahui bahwa dalam proses pembelajaran matematika guru dan siswa belum didukung dengan bahan ajar yang dapat membatu siswa dalam mengkaji materi yang telah diterima sesuai dengan karakteristik belajar masing-masing individu, maka penulis mengembangkan produk berupa bahan ajar berbasis IT, penentuan judul dan indikator disesuaikan dengan kompetensi yang bersangkutan berdasarkan silabus. Pemaparan analisis kebutuhan yang dilakukan peneliti sesuai dengan langkahlangkah analisis kebutuhan, yaitu: 1) menetapkan kompetensi yang telah dirumuskan pada silabus; 2) mengidentifikasi dan menentukan ruang lingkup unit kompetensi atau bagian dari kompetensi utama; 3) mengidentifikasi dan menentukan pengetahuan, keterampilan dan sikap yang dipersyaratkan; dan 4) menentukan judul modul yang akan disusun (Asyhar, 2012).

Pemilihan bahan ajar berbasis IT sebagai pendukung dalam pembuatan media pada bahan ajar yang dikembangkan dikarena perkembangan zaman dan teknologi sehingga menyebabkan penggunaan media pembelajaran yang paling tepat adalah bahan ajar berbasis IT. Hal ini juga dikarena bahan ajar berbasis IT mampu menjelaskan materi dengan lebih menarik dan lebih detail. Pernyataan ini diperkuat dengan pernyataan Daryanto yang mengemukakan bahwa kehadiran media pembelajaran berbasis teknologi dan informasi dapat membantu dalam menyampaikan materi secara lebih detail serta lebih menarik perhatian siswa untuk belajar.

Selain itu, juga dalam penggunaannya media berbasis komputer lebih mudah, dan tidak menguras tenaga serta pemanfaatannya tidak lagi dibatasi oleh ruang dan waktu. Sejalan dengan teori yang dikemukakan oleh Choiron bahwa komputer efektif digunakan dalam pelaksanakan pembelajaran, dikarenakan: 1) dapat memperluas dan mempermudah akses informasi dalam pembelajaran dengan cepat; 2) dapat membantu memvisualisasikan materi-materi yang bersifat 
abstrak; 3) dapat menampilkan materi pembelajaran menjadi lebih menarik; dan 4) memungkinkan terjadinya interaksi dengan materi yang sedang dipelajari (Ferti Anggraeni, Undang Rosidin, 2011). Perangkat lunak pembelajaran mempunyai empat keunggulan, yaitu 1) Melatih siswa mengeksplorasi konsep, 2) Meningkatkan kemampuan bernalar, 3) Mendorong siswa berpikir sistematis, logis dan analitis dan 4) Meningkatkan minat siswa untuk belajar matematika (Sumarni, Anggar Titis Prayitno, 2017).

Temuan dalam artikel ini secara praktis dapat ditindaklanjuti oleh penulis dan pihak sekolah dalam membenahi bahan ajar yang digunakan oleh guru matematika. Guru juga harus terus menggali potensi dan kebutuhan lokal yang layak diintegrasikan dalam pembelajaran matematika, sehingga pembelajaran menjadi bermakna, menyenangkan, dan berkelanjutan. Tanpa adanya perubahan sikap di kalangan guru-guru, implementasi bahan ajar berbasis IT di tingkat kelas akan mengalami kegagalan.

\section{REFERENSI}

Anwar, R. (2013). Hal-Hal Yang Mendasari Penerapan Kurikulum 2013. Humaniora, (45), 97-106.

Asyhar, R. (2012). Kreatif Mengembangkan Media Pembelajaran. Jakarta: Gaung Persada (GP) Press Jakarta.

Departemen Pendidikan Nasional. (2008). Panduan Pengembangan Bahan Ajar. Jakarta: DEPDIKNAS.

Direktorat Pembinaan SMA. (2010). Juknis Pengembangan Baban Ajar SMA. Jakarta: Dikmen.

Ferti Anggraeni, Undang Rosidin, W. S. (2011). Perbandingan Hasil Belajar Menggunakan LKS Berbasis Laboraturium Virtual Dengan LKS Konvensional. FKIP Unila, 1(1), 93-106.

Halidi, Hasan Mahmud, S. N. H. dan S. S. (2015). Pengaruh Media Pembelajaran Berbasis TIK terhadap Motivasi dan Hasil Belajar IPA Siswa Kelas V SDN Model Terpadu Madani Palu. E-Jurnal Mitra Sains, 3(1), 53-60.

Ibrahim. (2015). Deskripsi Implementasi Kurikulum 2013 Dalam Proses Pembelajaran Matematika di SMA Negeri 3 Maros Kabupaten Maros. Jurnal Daya Matematis, 3(3), 370_ 378.

Ika Lestari. (2011). Pengembangan Bahan Ajar Berbasis Kompetensi. Padang: Akademia.

Jenny Indrastoeti SP, S. I. (2017). Analisis Kebutuhan Pengembangan Bahan Ajar Evaluasi Pembelajaran di PGSD Dengan Pendekatan Kontekstual. Proseding: INOVASI PENDIDIKAN Bunga Rampai Kajian Pendidikan Karakter, Literasi, Dan Kompetensi Pendidik Dalam Menghadapi Abad 21, 1(1), 266-279.

Kaushik, A., \& Singh, A. K. (2013). Long Term Forecasting with Fuzzy Time Series and Neural Network : a comparative study using Sugar production data, 4(7), 2299-2305.

Machali, I. (2014). Kebijakan Perubahan Kurikulum 2013 dalam Menyongsong Indonesia Emas Tahun 2045. Jurnal Pendidikan Islam, IIII, 71-94. https://doi.org/10.14421/jpi.2014.31.7194

Maharani, A. (2017). Pengembangan Bahan Ajar Matematika Berbasis Macromedia Flash Materi Operasi Bilangan Real SMK Teknologi \& Rekayasa. Jurnal Teori Dan Riset Matematika (TEOREMA), 2(1), 1-10.

Mira Susanti, Nevrita, A. N. P. (2017). Implementasi Standar Proses Kurikulum 2013 Pada Pembelajaran Biologi di MAN Tanjungpinang. Jurnal Umrah, 1(8), 1-9.

Mochamad Guntur, Arif Muchyidin, W. W. (2017). Pengaruh Penggunaan Bahan Ajar Matematika Bersuplemen Komik terhadap Kemandirian Belajar Siswa Tadris Matematika Institut Agama Islam Negeri ( IAIN) Syekh Nurjati Cirebon. EduMa, 6(1), 43-51. 
Saluky. (2016). Pengembangan Bahan Ajar Matematika Berbasis Web Dengan Menggunakan Wordpress. EduMa, 5(1), 80-90.

Sumarni, Anggar Titis Prayitno, M. N. (2017). Pengembangan Bahan Ajar Matematika Ekonomi Berbasis Berbantuan Untuk Meningkatkan Hasil Belajar Mahasiswa. JES-MAT, 3(2), 139_ 154. 